Cletus C. Coughlin and Kenneth C. Carraro

Cletus $C$. Coughlin is a senior economist and Kenneth C. Carraro is an economist at the federal Reserve Bank of St. Louis. Thomas A. Pollmann provided research assistance. The authors also would like to thank Kenneth W. Bailey for providing data and helpful suggestions.

\title{
The Dubious Success of Export Subsidies for Wheat
}

N MAY 15, 1985, the U.S. Department of Agriculture introduced an export subsidy program called the Export Enhancement Program (EEP). The program's main goal is to increase U.S. agricultural exports.' The program also is intended to induce European Community (EC) reductions in agricultural subsidies during the cument round of multilateral trade negotiations under the General Agreement on Tariffs and Trade (GATT).

Although the EEP focuses on exports and trade policies, it is a direct outgrowth of the domestic farm policies of the United States and the European Community. The above-market price guarantees of these policies have resulted in surplus production. To dispose of these surpluses, many governments have chosen to subsidize agricultural exports.
This paper examines the EEP's primary goal of expanding exports in the context of disposing of government-owned wheat. Other research is used to compare the cost of reducing wheat stocks via the EEP with the cost of simply destroying the wheat. Although this paper focuses on wheat, chiefly because wheat has accounted for the bulk of EEP activity, the economic principles used here can be generalized to similar programs for other commodities.

The secondary goal of influencing $\mathrm{EC}$ farm policy is analyzed in the framework of the current round of GATT talks. In 1985, the United States proposed that all trade- and production-distorting subsidies be eliminated over a 10 -year period. ${ }^{3}$ Other groups, including the EC and the Cairns

\section{U.S. Department of Agriculture (May 1988).}

2The General Agreement on Tariffs and Trade contains the international rules governing export subsidies. Article XV: 4 protibits export subsidies on industrial products that lead to export sales at lower prices than domestic sales; however, this does not apply to agriculiural goods. U.S. farm interests were sufficiently powerful to prevent the prohibition on export subsidies from encompassing agricuitural goods. Article XV: 3 recommends that export subsidies on agricultural goods be avoided, but, if they are used, the subsidizing country should not garner a "more-than-equitable" share of trade for the good. While European farm interests prevented the extension of the export subsidy prohibition to agricultural goods in the Tokyo Round of Multilateral Trade Negotiations (1974-79), the meaning of equitable was clarified. For example, a more-thanequitable share includes the displacement of another country's exports. A teference period of the three most recent years in which normal market conditions existed is to be used in determining an equitable share. See Hufbauer and Erb (1984) for additional detals.

Roningen, Sulivan and Wainto (1987) estimate annual welfare gains for the United States of slightly less than $\$ 4$ billion from a multilateral removal of these measures. 
Group, have offered altemative proposals.' The primary reason for changing the current agricultural policies that benefit domestic farmers at the expense of consumers, taxpayers and others is the cost of such programs. For example, the ministers of the Organization for Economic Cooperation and Development recently stated:

The cost of agricultural policies is considerable, for government budgets, for consumers and for the econony as a whole. Moreover, excessive support policies entail an increasing distortion of competition on world markets; run counter to the principle of comparative advantage which is at the root of intemational trade; and severely damage the situation of many developing countries. ${ }^{3}$

This paper examines EEP's role in encouraging successful negotiations to liberalize agricultural trade in the GATT process.

Before examining the issues of export expansion and trade negotiations, we describe the export subsidy programs of the United States and Furopean Community and, in the process, provide historical background necessary to understand the EEP's objectives.

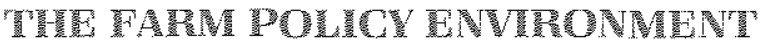

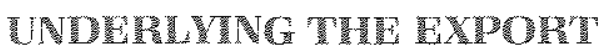

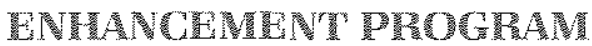

The stage for this export subsidy program was set by steady losses in the share of world agricultumal trade held by the United States and by paral lel EC gains in export shares. From 1977 to 1985 , the U.S. share of the world's net wheat exports declined from 41.9 percent to 28.8 percent, while the EC's share rose from -1.6 percent to 15.1 percent. ${ }^{6}$ These changing market shares can be linked to EC export subsidies. Chart 1 shows that the U.S. wheat export price generally exceeded the subsidized EC export price between 1978 and 1987 . Since 1983, the gap has tended to widen. IC export subsidies are responsible for this gap because internal $\mathrm{EC}$ prices are far above U.S. market prices. This LC subsidy is the catalyst for the U.S. export subsidy program, which is targeted at those coun- tries where EC-subsidized exports have displaced U.S. exports.

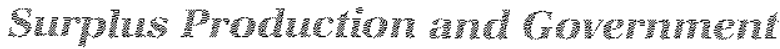 Whent Stroths}

To understand the EEP goal of export expansion, one must examine the U.S. farm programs used to support the production of most crops. The most important consequence of these programs is that they generate surpluses because price guarantees, with the exception of the early 1970s, have been above market-clearing levels. There are two main instruments of the crop programs: loan rates and target prices. Both are price guarantees that are announced well before farmers make planting decisions. To participate in these programs, farmers generally have been required to reduce crop acreage. For example, wheat farmers must set aside 10 percent of their 1989 wheat acreage base to qualify for the wheat price support program.

The loan rate, set at $\$ 2.06 \mathrm{per}$ bushel for the 1989 wheat crop, serves as a price floor. If the market price is lower than $\$ 2.06$, a farmer pledges the wheat crop to the government as collateral in exchange for a "loan" of $\$ 2.06$ per bushel. If the price of wheat rises above the loan rate, the farmer can repay the loan with interest, recover the crop and sell at the higher matket price. If the market price does not recover, the famer defauls on the "loan," thus ceding the crop to the government. By law, the govemment keeps the acquired surpluses off the market until the price reaches a higher level, known as the release price, at which time the surpluses can be sold on the market.

While the loan rate acts as an explicit price support the target price functions as an explicit income support device and is the final price that farmers receive for their crop. At the end of a crop year, farmers receive "deficiency payments" equal to the difference between the target price and either the market price or the loan rate, depending

EC was a net importer of wheat in that year. EC dala have been calculated for the EC- $\$ 2$ and exclude intra-EC trade.

These data are not adjusted for wheat quality and transportation differentials. Such differentials, however, are relatively constant and thereiore, do not distort significantty the rising price gap trend. the proposals by the United States, the European Community the Cairns Group, Japan and Canada. The Catrns Group consists of Canada, Australia, New Zealand, Indonesia, Malaysia, the Philippines, Thailand, Brazil, Uruguay, Argentina, Columbia, Hungary and Chile.

see Wilson (1988), p. 5.

6Net wheat exports zepresent exports minus impors. The nega tive market share figure for the $\mathrm{EC}$ in 1977 indicates that the 


\section{Chart 1}

\section{U.S. and EC Wheat Price Differential ${ }^{4}$}

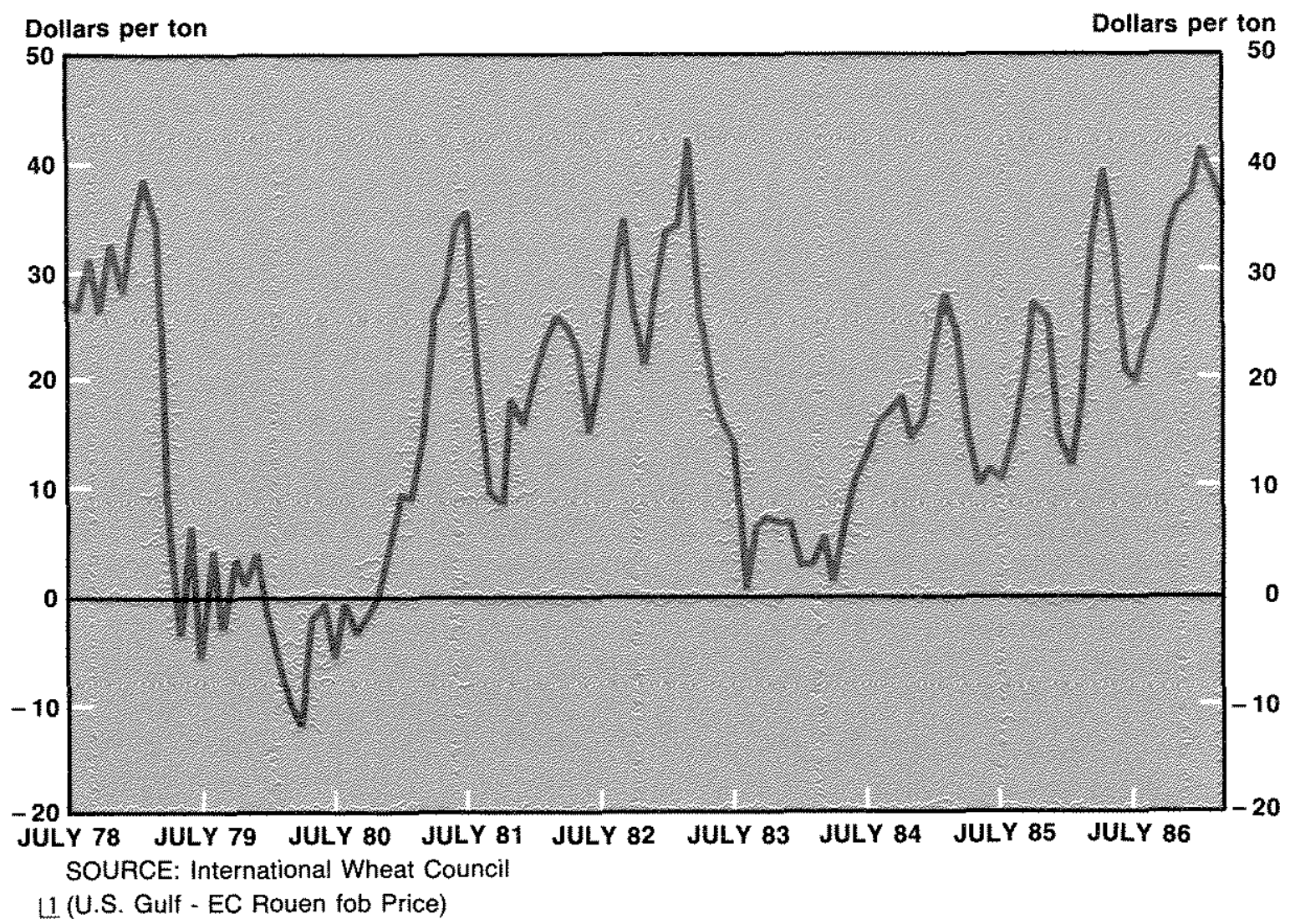

on which is higher. "Table 1 shows the target, loan rate and market prices since the introduction of the target price mechanism in the crop year ending June 30, 1975. For 1988, the target price was $\$ 4.38$ per bushel. Since the higher of the market price and loan rate was the market price of $\$ 2.60$ per bushel, the deficiency payment was $\$ 1.78$ per bushel. Until 1988, the deficiency payment rose throughout the 1980s.

As suggested above, as the market price declines relative to the loan rate, farmers find it more profitable to surrender their crops to the government for the loan rate price rather than sell on the market. These surplus stocks are accumulated by the Commodity Credit Corporation, the agency of the U.S. Department of Argiculture (USDA) charged with the administration of the price support pro- grams. Chart 2 shows the inverse relationship between the accumulation of wheat stocks and the price gap measured by the market price minus the loan rate. When the price gap increases because of crop shortages or strong demand such as in the early 1970 s, stoeks are reduced. When the price gap narows, and especially if the gap is negative, the accumulation of stocks occurs. The lange increase in wheat stocks in the 1980 s reflects the relatively small price gap.

\section{Disposing of Coverwment Wheat Stocks}

Various programs are used to dispose of the stocks that are owned by the government. Some of the surplus disposal is directed to the domestic market, but most is directed to foreign markets 
Table 1

U.S. Wheat Prices (dollars per bushel)

\begin{tabular}{lcccc}
\hline Year & $\begin{array}{c}\text { Target } \\
\text { price }\end{array}$ & $\begin{array}{c}\text { Loan } \\
\text { rate }\end{array}$ & $\begin{array}{c}\text { Market } \\
\text { price }\end{array}$ & $\begin{array}{c}\text { Deficiency } \\
\text { payment }\end{array}$ \\
\hline 1975 & $\$ 2.05$ & $\$ 1.37$ & $\$ 4.09$ & $\$ 0.00$ \\
1976 & 2.05 & 1.37 & 3.56 & 0.00 \\
1977 & 2.29 & 2.25 & 2.73 & 0.00 \\
1978 & 2.90 & 2.25 & 2.33 & 0.65 \\
$19 / 9$ & 3.40 & 2.35 & $2.9 /$ & 0.52 \\
1980 & 3.40 & 2.50 & 3.80 & 0.00 \\
1981 & 3.63 & 3.00 & 3.99 & 0.00 \\
1982 & 3.81 & 3.20 & 3.69 & 0.15 \\
1983 & 4.05 & 3.55 & 3.45 & 0.50 \\
1984 & 4.30 & 3.65 & 3.51 & 0.65 \\
1985 & 4.38 & 3.30 & 3.39 & 1.00 \\
1986 & 4.38 & 3.30 & 3.08 & 1.08 \\
1987 & 4.38 & 2.40 & 2.42 & 1.98 \\
1988 & 4.38 & 2.28 & 2.60 & 1.78 \\
1989 & 4.10 & 2.06 & NA & NA \\
\hline
\end{tabular}

The year ending June 30

${ }^{2}$ Average price received by farmers

SOURCE: Wheat Situation and Outlook (February 1988), p. 20

Chart 2

\section{Surplus Wheat Stocks and the Price Gap of the Wheat Market Price minus Wheat Loan Rate}

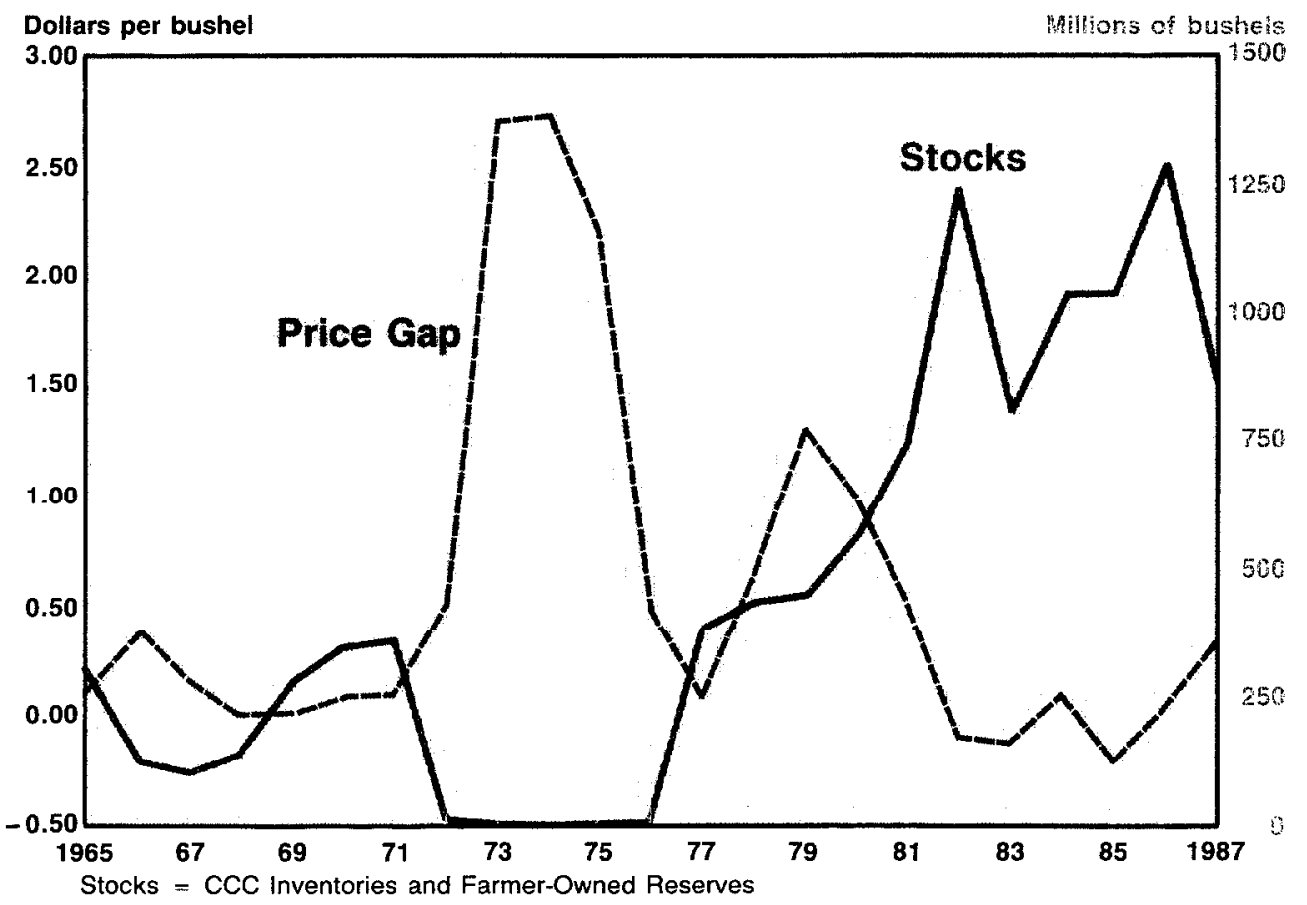




\section{Table 2}

\section{Export Subsidies by the United States Under the EEP and Export Restitutions by the European Community (millions of U.S. dollars)}

\begin{tabular}{|c|c|c|c|c|}
\hline \multirow[b]{2}{*}{ Year } & \multicolumn{2}{|c|}{ United States: } & \multicolumn{2}{|c|}{ European connurity? } \\
\hline & $\begin{array}{l}\text { Total } \\
\text { GEP }\end{array}$ & $\begin{array}{l}\text { Wheat } \\
\text { Emp }\end{array}$ & 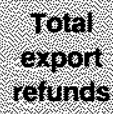 & 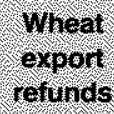 \\
\hline $\begin{array}{l}1982 \\
1988 \\
1986 \\
1986 \\
1986 \\
1987 \\
1988\end{array}$ & $\begin{array}{l}500 \\
907 \\
905\end{array}$ & $\begin{array}{r}209 \\
70 \\
744\end{array}$ & $\begin{array}{r}54,668 \\
4,647 \\
4,895 \\
6,028 \\
7,121 \\
10,245 \\
12,861\end{array}$ & $\begin{array}{l}8560 \\
720 \\
380 \\
365 \\
68 \\
11 \\
N A\end{array}$ \\
\hline
\end{tabular}

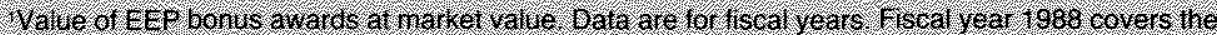

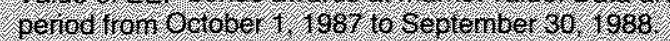

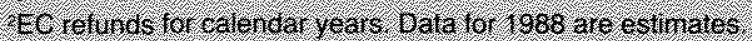

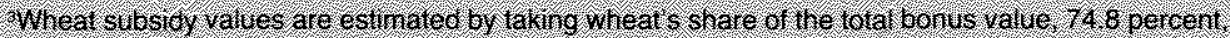
and apeyng this percert to totarsubsidy value.

through export." Obviously, the EEP belongs to the latter category."

More than 100 initiatives, targeting more than 60 countries and 11 commodities have been announced under the EEP since June 1985. The EEP functions by giving govemment-owned surplus commodities at no cost to private U.S. exporters. This allows them to sell U.S. commodities at prices that are below U.S. market prices in order to be competitive with other export-subsidizing countries. An EFPsales initiative states the taigeted country and the quant ity of a specific commodity to be sold. Knowing that a subsidy is available, private U.S. exporters can offer to sell the commodity at prices below the market cost of acquiring it in the United States. These bids are contingent upon receiving the necessary subsidy from the USDA.

The foreign buyer may accept bids made by numerous U.S. exporters. The U.S. exporters then bid against each other to receive the USDA's surplus stocks as a payment for the export subsidy. During this process, each exporter states how large a subsidy is required to make the export sale. For example, if one exporter requests a subsidy of $\$ 30$ per ton and another requests $\$ 35$ per ton for sale of the same commodity to the same country, the USDA would award the subsidy payment to the lower bidder. Thus, the bid process helps the USDA get a larger volume of exports per dollar of subsidy. If the exporter's bid for the subsidy is successful, the commodity sale to the foreign country is made; otherwise, the sale to the foreign country is voided. Upon proof of shipment and landing of the commodity in the targeted market the exporter is paid by the USDA with a generic commodity certificate in the amount of the bonus. The certificate can be exchanged for its value in any of the surplus stocks held by the USDA. The exchange of certificates for most commodities is made at the "Posted County Price," which is representative of an average local market price. The exchange of certificates for wheat is accomplished through a USDA auction.

As shown in table 2, EEP subsidies have increased since their inception in 1985. Total EEP
SOne of the most notable examples of domestic surplus disposal was the 1983 Paymentmmkind (PIK) program that gave surplus commodities to famers who agreed to limit their production. The school milk program, which sells mik at below market prices, and programs to distribute other datry products to food-stamp recipients are ofher domestic examples of surplus disposa policy

\footnotetext{
10Another example of surplus disposal through export is the Food for Peace Program, also known as P.L. 480. The program provides surpluses either at no cost or at below-market prices to low-income courtries. In an analysis of P.L. 480 , Luttrelt (1982) concluded that the tood shipments were largely a gift that reduced the incentive for food production in the reciptent nations.
} 
subsidies in fiscal year 1986 amounted to $\$ 280$ million and grew to $\$ 995$ million in 1988 . During this time, the value of wheat subsidies grew from $\$ 209$ million to $\$ 744$ million. Had it not been slowed by the severe drought in the United States that reduced the availability of wheat surpluses, EEP growth in 1988 would have been even more stubstantial.

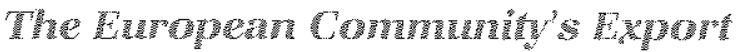 Refunts}

While the EEP is of recent origin, the EC's export subsidy program has been in effect since the founding of the Common Agricultural Policy (CAP) in 1962. The program, however, was not a source of trade friction with other agricultural exporting nations because the EC was an importer of most agricultural commodities. The CAP originally was designed to encourage domestic production in Europe following the food shortages during and after World War II. It encourages commodity production by offering a guaranteed price that often has been significantly higher than the world price. Because domestic prices generally have been higher than world prices, the CAP uses a variable levy to protect EC farmers from lower-priced imports."

Over time, European famers responded to the high price guarantees with greatly increased production, resulting in large surplus stocks. To dispose of the surpluses, the EC makes payments to exporters, known as export restitutions or refunds, to allow them to sell the higher-priced EC commodities at the lower world price. As CAP price guarantees have remained above world market prices, export subsidies have expanded futher to dispose of the mounting surpluses. Export refunds by the EC have grown from $\$ 4.7$ billion in 1982 to a projected $\$ 12.9$ billion in 1988 . Bailey (1988a) states that EC export subsidies for wheat rose from $\$ 365$ million in 1985 to an estimated $\$ 1.8$ billion in 1988 and that the EEP probably accounted for 35 percent to 40 percent of the increase. ."

\section{ANA

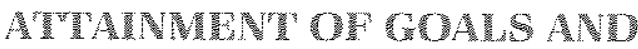 Costs}

The EEP will be judged on the basis of the costs associated with expanding exports and inducing negotiations to liberalize agriculture throughout the world. First, we examine the effect of the EEP on exports and assess its costs relative to simply destroying the surplus production. Second, we examine the effect of the EEP on the EC's willingness to reduce governmental involvement in agricultural production and trade.

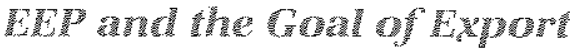 Eumensing}

The primary goal of the EF.P is to increase the volume of U.S. agricultural exports. Wheat exports have increased sharply since 1985 , the first vear of the EEP, growing about 60 percent in 1987 . Not only has the level of exports expanded, but the U.S. share of the world's wheat market increased from 28.8 percent in 1985 to an estimated 41.6 percent in 1988. To what extent can the rise in exports be attributed to the EEP? The following discussion highlights many of the empirical difficulties involved in answering this question and discusses one study that has addressed this question.

The EEP, as an export subsidy program, will increase the quantity of exports by driving down the price of exports. As Belongta (1986) has noted, however, export revenues will not necessarily rise as the quantity of exports increases. ${ }^{\text {s. }}$ If the world demand for wheat is inelastic, then the EEP would cause a reduction in export revenues. Therefore, the price elasticity of export demand for U.S. wheat is a crucial variable for determining the overall effects of the EEP.

Estimates of the price elasticity of export demand for U.S. wheat cover a wide range of values. Gardiner and Dixit (1987) summarized studies over the past two decades that estimated this elasticity.
1The variable fevy taxes imports at the rate of the difference between the world price and the EC threshold price. For exam. ple, in March 1987, the $\mathrm{EC}$ threshold price for wheat was $\$ 8.53$ per bushel while the world price was $\$ 1.95$ per bushel. $\mathrm{tm}$ porters would have been required to pay a levy of $\$ 6.58$ (\$8.53 -\$1.95). These payments represented a large income source for the EC when it was a major importer.

t2The EEP is only one device that the United States allegedly has used to influence the EC. The Farm Bill of 1985 sharply cut the crop loan rate which allowed the market price to plunge while maintaining a high level of income support for tamers.
This cut in market prices led to higher export subsidy costs for the $\mathrm{EC}$. In addition, the $1985 \mathrm{Farm}$ Bill introduced the practice of marketing loans for cotton and rice. The marketing loans also led to lower world prices while maintaining tarmers' in come. Cotton and rice, however, are not exported in any significant quantities by the $\mathrm{EC}$.

:See Belongia (1986) for a discussion of the profitabifity of farming and the pitfalls of using export volume as an indicator of the farm sector's economic health. 
The short-run (that is, one year or less) price elasticity ranged from -0.14 to -3.13 with an average of -0.72 , while the long-run that is, more than one yearl price elasticity ranged from -0.23 to -6.72 with an average of -1.93 . The lack of a consensus estimate precludes a definitive assessment about the desirability of EEP; however, some suggestive evidence can be assembled.

With 14 of the 17 estimates of the short-run price elasticity in the inelastic range, evidence suggests that increasing expott subsidies will de" crease export revenues in the short-run. A onetime, across-the-board subsidy is clearly unwarranted in this case. ${ }^{++}$

If the export subsidy continues, then the longrun price elasticity is relevant. A definitive conclusion is no longer possible. The studies suggest that the long-run price elasticity is likely to be elastic. If so, then export revenues will increase in the longmun due to the export subsidies. With export reve nues likely decreasing in the short-run and increasing in the long-run, additional information about the magnitudes of the export revenues and subsidy costs over time and the appropriate discount rate is required before a definitive conclusion can be reached.

In fact, information requirements are even greater. An implicit assumption of the elasticity discussion is that the $\mathrm{EC}$, as well as other countries, do not attempt to counteract the EEP. The parallel rise in U.S. and EC export subsidies, as well as anecdotal evidence presented later, reveals this assumption is not approprate. In addition, the EEP is targeted to specific markets where U.S. exports have been displaced by the $\mathrm{EC}$. Thus, information is required about the price elasticity of export demand for specific markets. Consensus estimates concerning specific markets are simply not avail-

14Using a model of international wheat markets, Sharples (1984) simulated the 1983 effects of an across-the-board $\$ 34$ per ton ( $\$ .93 /$ bushel) U.S. subsidy on its wheat exports. A specific goal was to compare the costs of using export subsidies to reduce surplus stocks with using the payment-in-kind acreagereduction program. Assuming the EC counter-subsidzed to maintain its existing volume of wheat exports, the U.S. subsidy would have caused a 300 million bushel increase in U.S. ex* ports, which represents a 20 percent increase above the level of unsubsidized exports. The direct budget cost would have totaled $\$ 1.6$ billion or approximately $\$ 5.30$ for each additional bushel of wheat exported. A less costly alternative would have been for the government to buy the additional 300 million bushels at the existing $\$ 3.65$ loan rate and then destroy it.

st The lower foreign exchange value of the dollar, which might be expected to have price effects similiar to an across-the-board subsidy, accounted for little of the increase in wheat exports.

16 The cost of the wheat subsidy for the two crop years $1986 / 87$ able. Finally, other factors that influence the level of U.S. wheat exports must be accounted for.

Despite the difficulty of estimating EEP's effect on export revenues, the EEP clearly has boosted the volume of wheat exports by eliminating the EC's export price advantage. Since 1985, the U.S. export price has been $\$ 30-\$ 40$ per ton higher than the subsidized EC export price, a difference offset by the average EEP subsidy of approximately $\$ 33$. The effect of this subsidy, along with four other factors that influenced U.S. wheat exports over the past three years, were analyzed by Bailey (1988b). These other factors were the lower price support loan rates for wheat, reductions in the vields of competing exporters, increased imports by the Soviet Union and the Peoples Republic of China not attributable to the EEP and finally the lower value of the dollar. Other factors that influence wheat exports, such as world economic health and production in importing countries, were not evaluated. Bailey found that the EEP was responsibe for about one-third of the increase in wheat exports from 1985 to 1987 attributable to the five factors. ${ }^{1.5}$ The EEP was responsible for roughly a 305 million bushel increase in wheat exports over $1986 / 87$ and $1987 / 88$. Over this same period, the cost of the EEP subsidy given to exporters for wheat sales was approximately $\$ 1.24$ billion."

These estimates translate to an approximate cost of $\$ 4.08$ for every bushel of increased exports. The average U.S. Gulf export price for wheat over these two years was only $\$ 3.16$. In terms of its $p \mathrm{~F}^{i-}$ mary goal, the EEP increased exports, but it did so at a high cost in the short-run. Destroying the govemment-owned stocks, which entails an opportunity cost of approximately $\$ 3.16$ per bushel, would be a more cost-effective form of surplus removal than the EEP with a cost of $\$ 4.08$ per bushel. and $1987 / 88$ was estimated because year by year cost data were not available. The share of total EEP wheat sales (through August 4, 1988) made in the two years was approximately 85 percent. The total market value of the wheat subsidies given to exporters through August 4, 1988 was $\$ 1.46$ billion. The twonyear cost of wheat subsidies theretore was estimated at $\$ 1.24$ billion ( $\$ 1.46$ billion times 85 percent).

"The avallability of surplus commodities is another important factor in the EEP which became apparent in the drought year of 1988 . When government stocks of wheat are depleted by drought or by other factors, the EEP program would be forced to reduce its activity. Such irregularity makes the program less reliable from the perspective of importing countries. The reaction of importers likely would be to diversify sources and reduce reliance on a single export source. In addition, the changes in the EEP possibly prevent the full impact of the rising exports from the higher price elasticities of demand in the long run from occurring. 


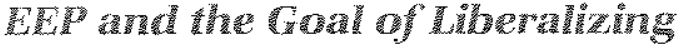 Agriculture Worlduide}

In addition to increasing exports, the EEP is being used to pressure the EC to liberalize its agricultural production and trade policies. By increasing the costs of the EC's agricultural support programs, the United States hopes to induce the European Community to negotiate major reductions in these programs. ${ }^{18}$ "The political nature of the agricultural programs of both the United States and the European Community preclude any definitive conclusions about the response of the $\mathrm{EC}$ to the EEP in the long run; however, insights from strategic trade theory and the observed initial EC responses that are identified below suggest the EEP has been ineffective."

In a strategic environment, a small number of economic agents make interdependent decisions." A decision by one agent can alter the costs and benefits facing another agent. Thus, agents attempt to judge the response of their rivals before determining the best course of action. Contrary to a world of perfect competition with many agents each too small to influence the market outcome, agricultural trade policy can be viewed as a strategic environment that can be altered by governmental decisions. Obviously, the United States and the $\mathrm{EC}$ are major decisionmakers in this environment.

Subsidies play an important role in strategic trade policy. Export subsidies have been recommended for strategic industries that are expected to earn additional retums sufficient to exceed the total cost of the subsidy. Strategic trade policy is controversial for a number of reasons, one of which is that strategic trade policy tends to create an adversarial situation between countries." Countries affected adversely are inclined to re- spond with their own subsidies. Mutually destructive trade wars are a distinct possibility. In fact, recent developments in world agricultural trade are characterized as part of a trade war." Without question, both U.S. and EC export subsidies for wheat have increased rapidly in recent years.

Paarlberg's (1988) recounting of the trade war between the United States and the EC provides a number of incidents that tend to reinforce the preceding discussion. In January 1983 , the United States subsidized the sale of 1 million tons of wheat flour to Egypt to undercut subsidized offerings by the $\mathrm{EC}$. To prevent the $\mathrm{EC}$ from buying back the market, the United States forced Egvpt to agree not to import wheat flour from any non-U.S. supplier until June 1984. In the short run, the United States displaced the EC sales of wheat flour to Egypt. The EC, however, responded by subsidizing exports of 320,000 tons of unmilled wheat to Egypt in spring 1983 and new subsidized wheat sales to Iran, Syria, Libya and Algeria. The EC also began competing in China and Latin America. In addition, it reached an agreement with Egypt in October 1983 on future subsidized sales.

One of the majof problems of the EEP in liberalizing agriculture is that mixed signals are being sent to the EC and other agricultural nations. The U.S. proposals are a highly publicized initiative to stimulate a cooperative search to reform agriculture through GATT. At the same time, the retalia tory challenges to European-subsidized expo:t sales can be termed "non-cooperative activism."

Tangermann (1985) argues that the U.S. export subsidies will be counterproductive in achieving a reduction of $\mathrm{EC}$ agricultural subsidies, His reasons are both politically and economically based. First. the EC's costs of matching the U.S. subsidies are relatively small. If U.S. subsidies had reduced world grain prices by 10 percent in 1982, the EC
s"The rising costs of the EC's agricuitural programs have already lead to some reductions in price supports. In 1984, the EC imposed dairy quotas and began charging farmers who ex* ceeded their quotas. More recently, the EC has stated its willingness to reduce grain support prices if grain production exceeds 160 million metric tons. The relationship of these cuts to the EEP, however, is unknown.

-Strategic trade theory has becorie popular because of recent developments that have focused on the importance of economies of scale, production experience and technological change as determinants of trade patterns. These determinants raise the possibility that productive resources such as labor and capital can eam higher returns in some industries than others and that certain sectors generate benelits that accrue to other sectors. Both possibilities can be used to jusity an activist use of trade policies to influence domestic as well as foreign activity and increase income domestically. Strategic trade theory combines international trade theory and political theory to explain the dynamics of trade policies and assist in designing policies that are in a nation's best interest.

$\approx$ See Pichardson (1986) for a more lengthy discussion of strategic trade policy.

2Subsidies for research and development have been recommended for strategic industries whose competitive positions depend on generating technological advances. In addition to creating an adversarial situation between countries, there are concerns that special interest groups will capture the benefits from the subsidies at the expense of the nation.

${ }^{22}$ See Lochthead (1988) for a characterization of this trade war. 
could have maintained its export volume by an increase in its agricultural budget of only 0.8 percent. Second, since the United States can be portrayed as the enemy, there will be much political support for expenditures to counteract the U.S. subsidies.

Additional doubts about the effectiveness and wisdom of waging full-scale trade war have been raised by Paarlberg (1988). Since the United States has much larger foreign markets to defend, Paarlberg estimates that it would have to outspend the European Community by 50 percent in a fullscale war simply to retain its market share. In addition, since some of the U.S. major foreign competitors are also large importers, a full-scale war would likely lead to foreign retaliation in the form of import restrictions that would be costly to both the United States and the other countries. As a major importer from the United States, the EC is in a position to make a full-scale war more costly for the United States.

In addition, the U.S. negotiating position in GATT is weakened because the United States is doing the same thing that is the source of its inritation with the EC." For example, the Cairns Group, a negotiating coalition of 13 agriculturally oriented nations, has objected strenuously to the continued use of agricultural export subsidies ${ }^{24}$ Much irritation stems directly from the economic consequences of increasing subsidies by the United States and the EC. Oleson (1987) has noted that the U.S. and EC policies have caused the price of wheat to fall, imposing major losses on such grain exporters as Canada, Australia and Argentina.

Strategic trade theory suggests that the lack of clarity about U.S. policy will inhibit the desired foreign response. The United States is willing to subsidize exports; however, it maintains that a liberalized agricultural system is a goal. A basic question, which focuses on the credibility of the U.S. proposal, is whether the goal of a complete liberalization of agricultural production and trade in the United States is feasible politically.

Producers of agricultural products in the United States have been beneficiaries of price support programs since the $1930 \mathrm{~s}$. $^{25}$ These programs provide substantial benefits to the farm sector.

23The EEP also has sparked a diplomatic controversy. The program was written to exclude subsidized sales to the Soviet Union. The Soviet Union used this discrimination as a basis for reneging on its commilment to purchase a minimum of 4 million tons of U.S. wheat each year. Under pressure from domestic producers and exporters, the exclusion was reversed and the Soviet Union became eligible for subsidies on 4 million tons
Roningen, Sullivan and Wainio (1987) estimate that a multilateral liberalization would cause a loss of U.S. producers' surplus of slightly less than $\$ 10$ billion. Thus, whether the U.S. Congress would actually support legislation for the complete liberalization of agricultural production and trade is uncertain. This uncertainty about the true U.S. position likely deters the EC from agreeing to the stated U.S. position.

\section{CONCHSOON}

The initial evidence from the Export Enhancement Program, although far from conclusive, raises doubts about the wisdom of U.S. agricultural export subsidies for wheat and, by implication, all commodities. While the EEP has contributed to increased U.S. wheat exports, the cost of disposing of the resultant surplus, even if one ignores the escalating U.S.-European Community trade war, is higher than the cost of simply destroying the wheat in the short-run. In addition, the U.S. has imposed costs on agricultural exporters throughout the world.

Strategic trade theory and the EC's initial response to the export program suggest that the EC will be more likely to escalate the trade war than agree to U.S. proposals for eliminating all production- and trade-distorting agricultural policies. This, however, does not rule out the possibility that negotiations to liberalize agriculture are doomed, but rather suggests that the EEP will be ineffective, and possibly counterproductive, in affecting the EC's position.

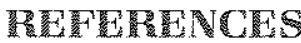

Bailey, Kenneth W. "What Explains Wheat Export Rise?" Agricultural Outlook (July 1988a), pp. 22-25.

"The Impact of the Food Security Act of 1985 on U.S. Wheat Exports: An Econometric Analysis." Ph D. Dissertation, Department of Agricultural and Applied Economics, University of Minnesota, September 1988b.

Belongia, Michael T. "The Farm Sector in the 1980s: Sudden Collapse or Steady Dowrturn?" this Review (November 1986), pp. 17-25.

Gardiner, Walser H., and Praveen M. Dixit. Price Elasticity of Export Demand: Concepts and Estimates, U.S. Department of Agricutture, Economic Research Service (February 1987).

This reversal embarrassed U.S. diplomats and angered major farm competitors such as Canada and Australiạ.

${ }^{24}$ See Houck (1988) for further details.

${ }^{25}$ See Gardner (1987) for a study using the public choice approach to explain producer protection across agricutural commodities since the 1930s. 
Gardner, Bruce L. "Causes of U.S. Farm Commodity Programs," Joumal of Political Economy (April 1987), pp. 290310.

Haley, Stephen L. Targeting of U.S. Agricultural Export Subsidies: A Theoretical Analysis, U.S. Department of Agriculture, Economic Research Service (June 1988).

Houck, James P. "What in the World is the Cains Group?" CHOICES (Second Quarter 1988), p. 34

Hufbater, Gary C., and Joanna S. Erb. Subsidies in Intemational Trade (Institute for International Economics, 1984).

Lochhead, Carolyn. "Disarmament Negotiations in the Agriculture Trade War," Insight (November 28, 1988), pp. 42-44.

Luttrell, Clifton B. "Good Intentions, Cheap Food and Counterpart Funds," this Review (November 1982), pp. 11-18.

Oleson, Brian T. "Wortd Grain Trade: An Economic Perspective of the Current Price War," Canadian Joumal of Agricultural Economics (November 1987), pp. 501-14.

Paarlberg, Robert L. Fixing Farm Trade (Ballinger Publishing Company, 1988).

Richardson, J. David. "The New Political Economy of Trade Policy," in Paul R. Krugman, ed., Strategic Trade Policy and the New International Economics (MIT Press, 1986), pp. 257m 82.
Roningen, Vemon, John Sullivan, and John Wainio. "The Impact of Removal of Support to Agriculture in Developed Countries," paper presented at the American Agricultural Economics Association meetings, August 1987.

Rossmiller, Ed. "Agricultural Proposals in the GATT," CHOICES (Second Quarter 1988), pp. 30-31.

Sharples, Jerry. "Are Export Subsidies the Answer to U.S. Grain Surpluses?" U.S. Department of Agriculture, Economic Research Service (October 1984).

Tangermann, Stefan. "The Repercussions of U.S. Agricultural Policies for the European Community," in Bruce L. Gardner, ed., U.S. Agricultural Policy: The 1985 Farm Legislation (American Enterprise Institute, 1985), pp. 329-44.

Wilson, Ewen M "A CHOICES Debate: Export Subsidies on Value-Added Products - Effects May Differ From Policy Objectives," CHOICES (Second Quarter 1988), pp. 5 and 7.

U.S. Department of Agriculture, Economic Research Service Wheat Situation and Outlook, various dates.

U.S. Department of Agriculture, Foreign Agricuttural Service. FAS Fact Sheet - Export Enhancement Program, revised May 1988.

World Production and Trade: Weekly Roundups, various dates. 